\title{
The Analysis of Vocational Students' Work Readiness in Pariaman and Padang Pariaman
}

\author{
Adi Afriadi ${ }^{1}$, Sri Ulfa Sentosa ${ }^{2}$, Marwan $^{3}$ \\ ${ }^{1}$ Faculty of Economics, Universitas Negeri Padang, Padang, Indonesia \\ $\triangle$ (e-mail) adiafriadi04@gmail.com \\ ${ }^{2}$ Dept. of Economics, Faculty of Economics, Universitas Negeri Padang, Padang, Indonesia \\ $\triangle$ (e-mail) sriulfasentosa@yahoo.com \\ ${ }^{3}$ Dept. of Economics Education, Faculty of Economics, Universitas Negeri Padang, Padang, Indonesia \\ $\square$ (e-mail) marwan.unpdg@gmail.com \\ $\triangle$ (e-mail) hasdiaimon1955@gmail.com
}

\begin{abstract}
This study aims to determine the influence of career guidance, self-efficacy and motivation to work on work readiness of students in Pariaman and Padang Pariaman. The data for this study were collected using a survey questionnaire. The sample was selected using proportional random sampling technique resulted with a sample of 184 vocational high school students in Business and Management major. The data were analyzed using structural equation modeling (SEM). The results show that the career guidance has a significant and positive impact on self-efficacy. The career guidance also has a significant and positive impact on students' motivation to work. Moreover, career guidance has a significant and positive impact on work readiness. Likewise, self-efficacy has a significant and positive impact on the motivation to work. Self-efficacy also has a significant and positive impact on work readiness. Finally, motivation to work has a significant and positive impact on students' work readiness.
\end{abstract}

Keywords: work readiness, career guidance, self-efficacy, motivation to enter the working world

\section{Introduction}

In the age of digital technology, the challenges of employment are increasingly dynamic and flexible. Both systems work and ways of working constantly changing. This requires an early understanding of job seekers. In addition, job seekers are required to have an understanding of industrial relations, in order to be able to compete in the labor market. Vocational high school (Sekolah Menengah KejuruanSMK) students must understand the emergence of new technology-based jobs, an increasingly competitive job market, as well as dynamic and flexible work challenges.

However, in Indonesia, the highest open unemployment contributor is the SMK graduates. Based on data from the Central Bureau of Statistics (Badan Pusat Statistik-BPS), the number of unemployed graduates from vocational schools is $9.84 \%$ in February 2016. In addition, there has been an increase in vocational graduates who have not worked since 2011 (Muktiani, 2014). Several studies related to work readiness have been done, among others by Mu'ayati and Margunani (2014), Noviana (2014), Willison (2015), Wasylkiw (2016) and Smith (2016). While some vocational school graduates continue their education to college, these studies report that a large number of vocational school graduates are not ready for work because the schools tend to only focused on academic achievement and overlooked the incorporation of work demanded skills in the school curriculum.

Work readiness is the ability with little or no help to locate and adjust to work requirements that is desired (Ward \& Riddle, 2002). Work readiness focuses on personal characteristics, such as the nature of workers and defense mechanisms needed, not only to get a job but also to maintain a job (Brady, 2010). Work readiness is a relatively new concept that has emerged in the literature as a criterion for predicting graduates (Cabellero, Walker, \& Tyszkiewicz, 2011). 
The analysis of work readiness in this research is focusing on the effect of career guidance, selfefficacy, and students' motivation to working. Each student is different, this self-understanding can be taught in career guidance service in schools (Fajriah \& Sudarma, 2017). Things to be achieved by students to be ready for work can be taught through career guidance to help them get a job suitable with their abilities (Zachim, 2014).

However, there is still a low level of students' participation in the career guidance service. Every day, the service only receives an average of 20 students from rangingfrom the first to the final year high school students. Moreover, this service is not a routinely performed service by schools. Theresa (2015) reports that the career guidance service does not get special attention from the students, leading to the student's limited career resources. A less optimal career guidance service can lead to unsuitable career selection and thus have an impact on students' work readiness after graduation. Previously, Theresa (2015) conducted a study on 420 students by involving 6 career counselors and 6 heads of institutions in Metropolis, Ghana. In contrast, this current study focuses its examination at vocational high school students of business and management major.

Another factor that affects the readiness of student work is self-efficacy. Self-efficacy is one's assessment of one's own ability to perform certain behaviors or specific goals (Ormrod, 2008). Selfefficacy affects the internal condition of a person's work readiness. So, to have a high self-efficacy can increase students' confidence to face the competition in business and industry (Noviana, 2014).

The problem of self-efficacy is low. It's like: unable to perform a difficult task, only to learn when the exam and their values are still below the minimum completeness criteria. (Noviana, 2014), said selfefficacy influences the internal condition of a person in a work readiness, so as to have a high selfefficacy can increase the confidence of students to dare to face the stiff competition in the business and the industrial. The difference from previous studies that research (Noviana, 2014), is only done in class XII program accounting expertise. While in this study conducted at SMK N class XII students of business and management expertise, which includes expertise programs Accounting, Administrative, and Marketing.

In addition, the motivation to enter the working world is an important thing to be aware of students. Motivation is the force that gives impetus for human behavior, which causes individuals to start and maintain measures aimed at specific purposes (Jenkins \& Demaray, 2011). Motivation determines the extent to which students will be encouraged to enter the working world (Pujianto 2017). Thus, the motivation to enter the working world be the impetus for students to meet their needs, so that later can reach the expected goals (Fajriah \& Sudarma, 2017).

The problem of motivation to enter the working world is the low motivation of students to enter the work of the world. They prefer to continue their education in college and get a job in part again yet. It is certainly not in accordance with a previous vocational goal, namely to produce graduates who are ready to work. (Pujianto, 2017), said the motivation to enter the working world are all things that encourage students to enter the working world in order to achieve certain goals. motivation to enter the working world determines the magnitude of the efforts of students to be accepted in the working world. The difference from previous studies that research (Pujianto, 2017), done in class XII student of Accounting and conducted only in one school is in SMK N 1 Batang. While in this research done on student class XII Accounting, Administrative, and Marketing and conducted at two schools that is, at SMK N 2 Pariaman and in SMK N 1 Enam Lingkung, Padang Pariaman.

Based on the phenomenon that has been described previously and supported by some relevant research which states that elsewhere in Indonesia there are still many vocational students who are not ready to work. This is of course not in accordance with the purpose of SMK as stipulated in the Government Regulation of the Republic of Indonesia number 17 of 2010, which expects SMK graduates ready for work. Given this very important issue, the authors are interested in conducting research with 
the aim of looking at the influence of career guidance, self-efficacy, and motivation to enter the workforce for readiness of business and management students in Pariaman and Padang Pariaman.

On the other hand, we consider this phenomenon as an opportunity to develop science, especially in education. Therefore, this needs to be considered by the community, educational institutions, and government. Looking at the framework of thought and theory that has been described before, then the data in this study were analyzed by using Structural Equation Modeling (SEM).

\section{Methods}

This study is a descriptive and associative research. The population in this study were all 337 students of class XII at vocational high schools (SMK) majoring in Business and Management in city of Pariaman and Padang Pariaman regency. In this study, the sample was determined by proportional random sampling technique that resulted with a sample of 184 students.

The 184 students comprised of 10 students of class XII in SMK Negeri 2 Pariaman and 4 studnets of classes XII in SMK Negeri 1 Enam Lingkung, Padang Pariaman. The students were selected randomly from each class and each school by using a lottery system.

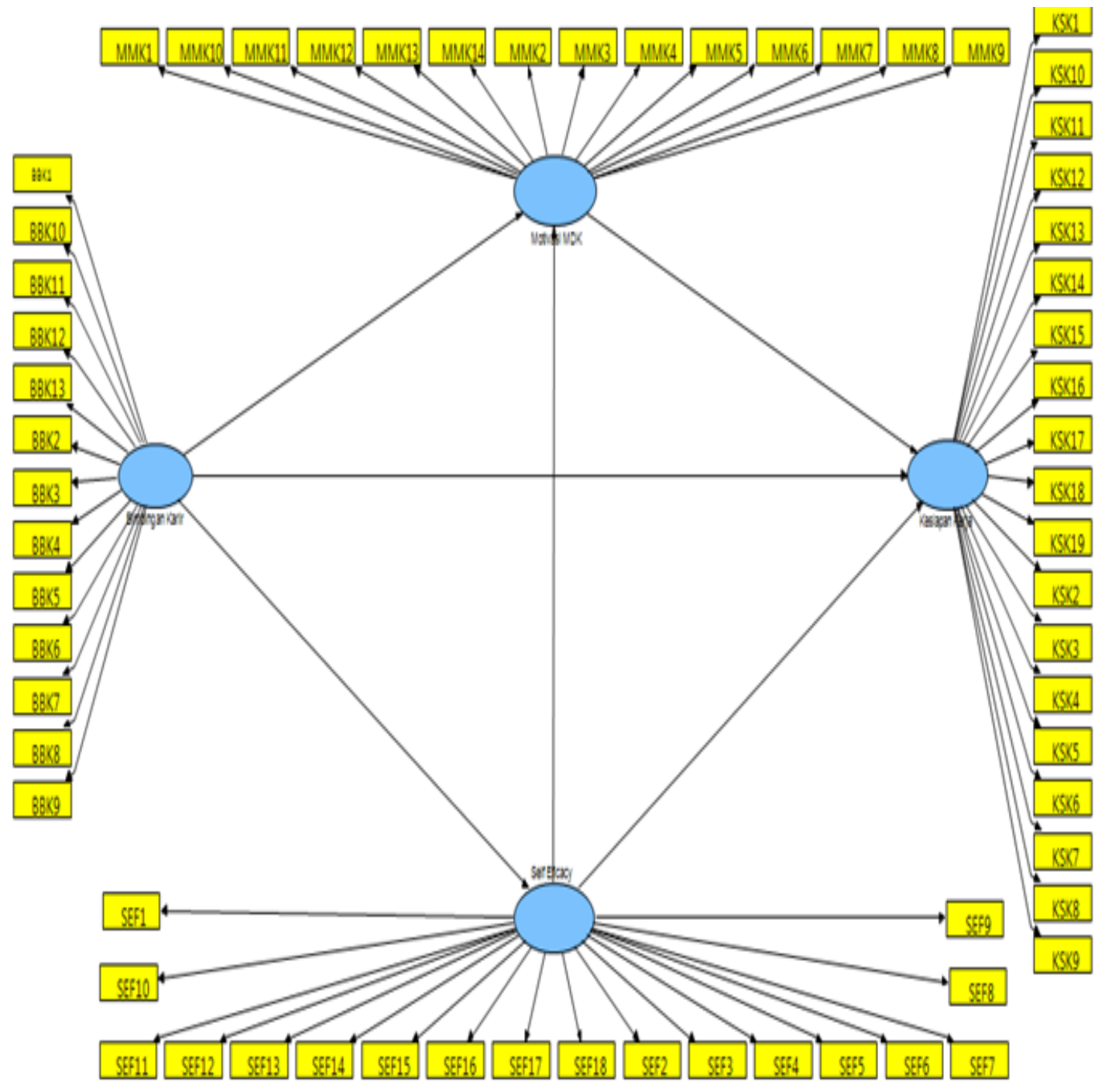

Figure 1 Conceptual Framework

This study used an instrument for data collection. The questionnaires were administered to 184 respondents to be answered using a 5-point Likert scale. In using a Likert scale, the variables to be 
measured are translated into the indicator variables. The indicator then used as a starting point to construct instrument items which can be a statement or a question. The Likert scale consists of five alternative answers and statements in the questionnaire were positive and negative statements. For a positive statement of the score were 5 for strongly agree, 4 for agree, 3 for doubtful, 2 for disagree, and 1 for strongly disagree. The reverse order of the scoring system was applied for a negative statement.

The data collected were tested for ensuring the instrument validity and reliability. The validity and reliability tests in this study was conducted using the outer test model. The outer model test consists of a test of convergent validity to describe the correlation between the constructs with indicators, test discriminant validity to describe the variables that should not be related, the correlation is declared invalid by the value of cross loading indicator is greater than the value of the correlation with latent variables other, and reliability testing for statements reflect consistency in the instrument and see the reliability of the dimensions and indicators.

The data were analyzed using the structural equation modeling (SEM). The SEM analysis tests the model measurement and structural simultaneously. Structural model is used to test the causality (hypothesis testing predictive models). SEM analysis requires two stages of assessment of a research model, namely, test models and test outer inner models. The outer test model was used to test the construct validity and reliability of the instrument. The inner model test is used to show the relationship between one latent variable and the others. The SEM analysis was conducted using partial least square (PLS) software. The conceptual framework formulated for this study is presented in Figure 1.

\section{Results and Discussion}

As explained earlier, the research was conducted by distributing questionnaires to 184 vocational high school students. The responses then tabulated and analyzed to show the frequency distribution The descriptions of the research variables are shown in Table 1 based on the respondents response level.

Table 1 The Frequency distribution of respondents

\begin{tabular}{cllll}
\hline No. & \multicolumn{1}{c}{ variable } & The average & TCR (\%) & Category \\
\hline 1. & Work Readiness & 4.45 & 85.17 & Very Good \\
2. & Career guidance & 4.13 & 82.74 & Very Good \\
3. & Self-efficacy & 4.06 & 81.22 & Very Good \\
4. & Motivation to work & 4.37 & 87.55 & Very Good \\
\hline
\end{tabular}

Source: The results of primary data processing, Jan 2018

Based on descriptive analysis, it can be seen that the respondents' level of achievement variable, job readiness, career counseling, self-efficacy and motivation to enter the work of work are in the very good category. This indicates that respondents were able to describe each variable very well.

The outer test of the model was conducted as well as the examination of instrument's construct validity and reliability related to each independent and the dependent variable. The results of convergent validity test show that work readiness variable is valid because of the loading factor value $\geq 0.5$. After some modifications by excluding three statements that were invalid, 16 statements related to career guidance variable were to be included in further testing. Meanwhile, the statements removed from the model were KSK 1, KSK 7, and KSK 16. The test results are shown in Figure 2 below.

Figure 2 shows that the indicators of work readiness in the model after the convergence validity test. Figure 2 reveals that there were three indicators excluded from the model because of the invalid value (the values $\leq 0.5$ ) such as indicators number 1,7 , and 16 . 


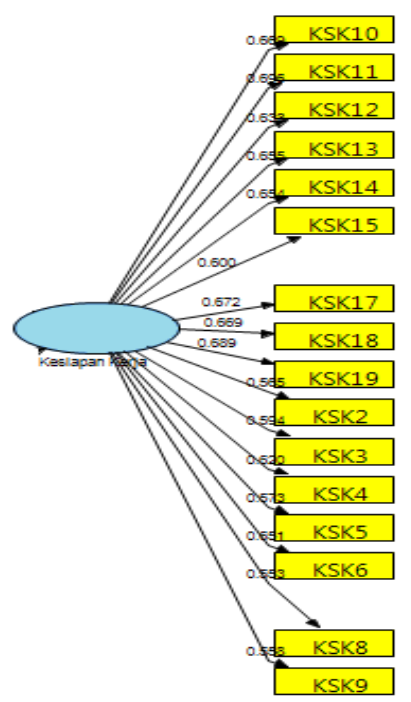

Figure 2 SEM Model for work readiness variable

The results of convergent validity show that career guidance variable is valid because of the loading factor value $\geq 0.5$. After some modifications by excluding three statements that were invalid, 10 statements from career guidance variable were to be included in further testing. Meanwhile, the statements removed from the model were BBK 4, BBK 5, and BBK 11. The test results are shown in Figure 3 below.

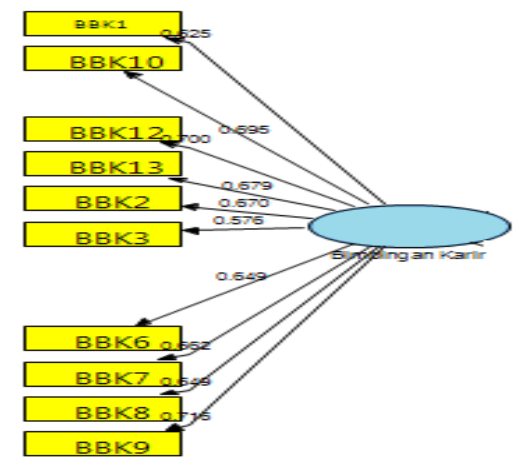

Figure 3 SEM Model for career guidance variable

Figure 3 describes the indicators of career guidance variable in the model after convergence test validity. The model shows that three indicators were excluded from the model because of the invalid value (the value $\leq 0.5$ ) such as BBK 4 , BBK 5 , and BBK 11 .

The results of convergent validity show that self-efficacy variable is valid because its loading factor $\geq 0.5$. After some modifications by eliminating three statements that are invalid, 15 statements of selfefficacy variable were to be included in further testing. The statement that were removed from the model were SEF statement 1, 7 and 11. The test results are show in Figure 4 below.

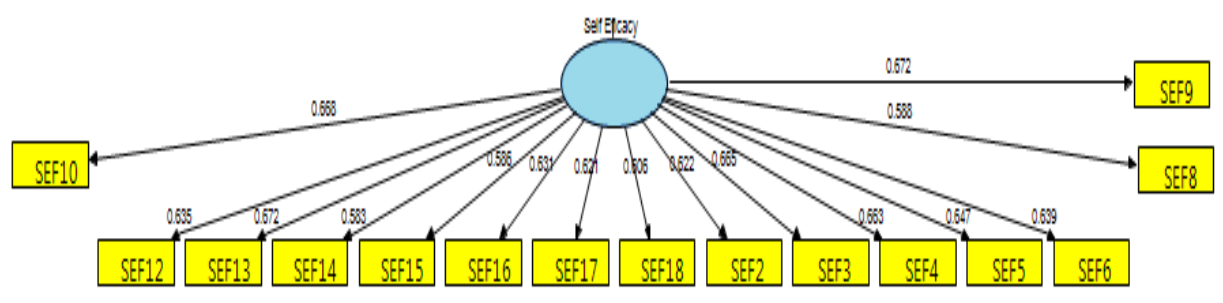

Figure 4 SEM Model for self-efficacy variable 
Figure 4 illustrates that the indicators of self-efficacy contained in the model after convergence test validity. The model shows that there are three indicators that were excluded from the model because of the invalid value, values $\leq 0.5$, such as indicators SEF 1,7 , and 11 .

The test results of convergent validity show that motivation to work is valid because of the loading factor value $\geq 0.5$. After some modifications by issuing three statements that are invalid, then gained as much as 11 statements from motivation to enter the work of world variables to be included in further testing. Meanwhile, the statements removed from the model were MMK 4, MMK 9, and MMK 12. The test result is presented in Figure 5 below.

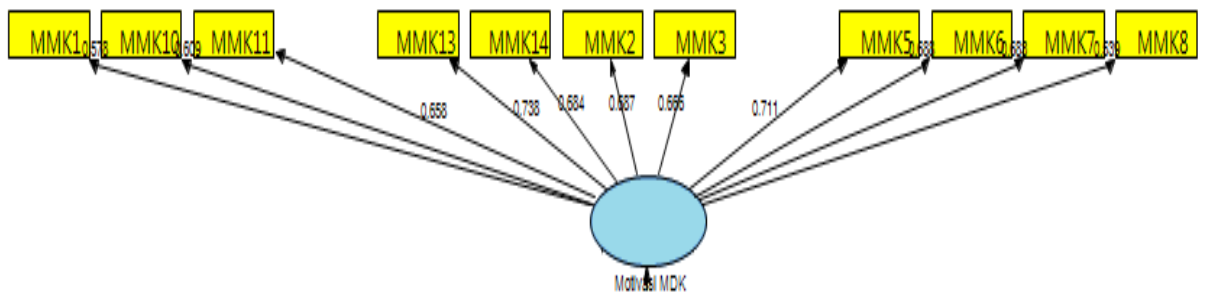

Figure 5 SEM Model for motivation to work variable

Figure 5 illustrates the indicators of motivation to enter the work of world variable that exists in the model after convergence test validity. The model shows that there were three indicators excluded from the model because of invalid values, values $\leq 0.5$, such as indicator number 4,9 , and 12 .

The consolidation of all four models in one new SEM model is shown in Figure 6.

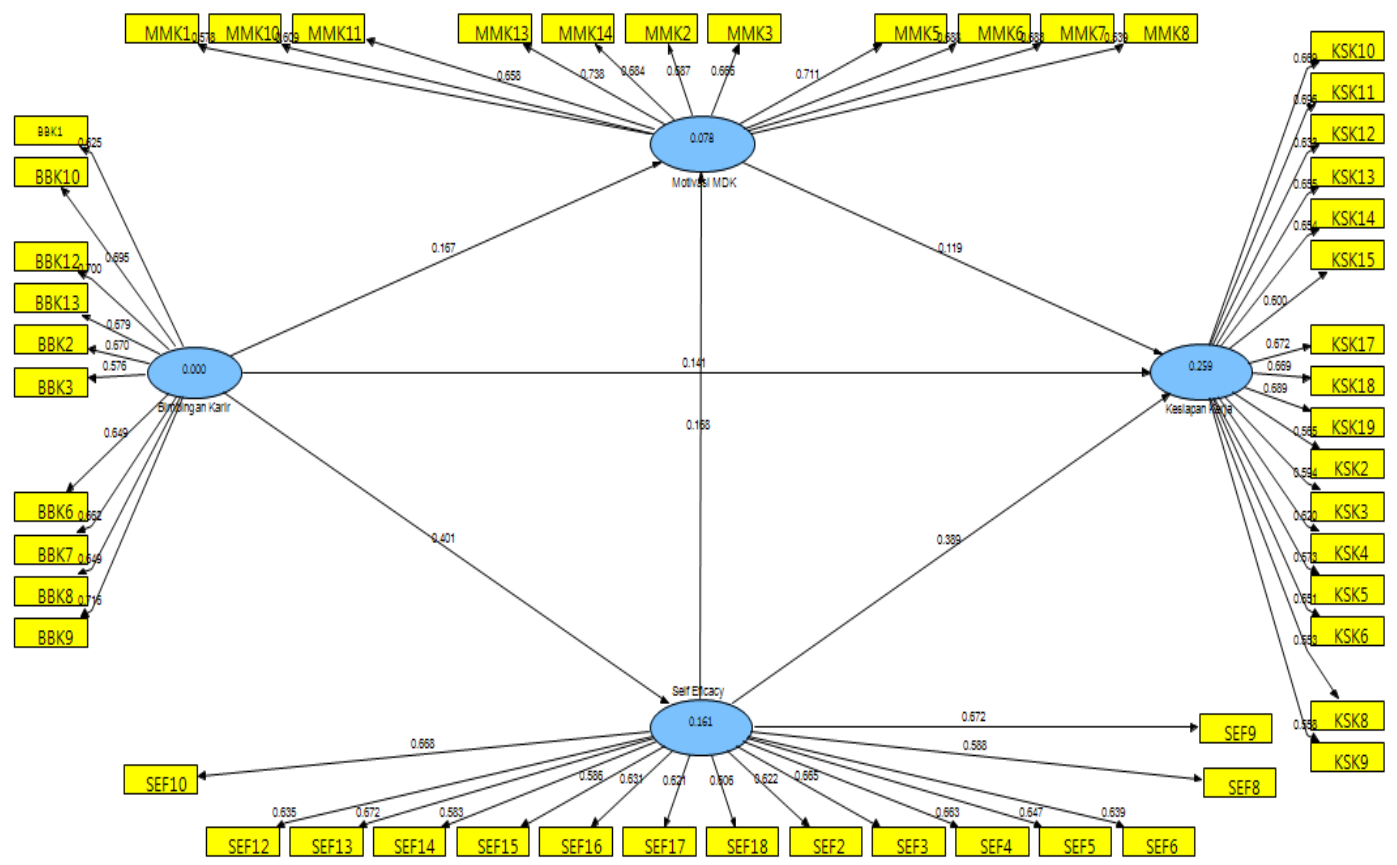

Figure 6 The final model for path analysis

The results of validity and reliability tests performed on the instrument, namely, the composite reliability and Cronbach's alpha values are shown in Table 2. The instrument is reliable if the values of Composite reliability and Cronbach's alpha are above 0.7 . 
Table 2 Results of the reliability test instruments

\begin{tabular}{lcl}
\hline Variable & Composite Reliability & Cronbach's Alpha \\
\hline Work Readiness $(\mathrm{Y})$ & 0.912 & 0.898 \\
Career Guidance $\left(\mathrm{X}_{1}\right)$ & 0.886 & 0.858 \\
Self-Efficacy $\left(\mathrm{X}_{2}\right)$ & 0.909 & 0.895 \\
Motivation to Work $\left(\mathrm{X}_{3}\right)$ & 0.894 & 0.869 \\
\hline
\end{tabular}

Source: The results of primary data processing, Feb. 2018

The results of the reliability test show that the composite reliability and Cronbach's alpha values for work readiness, career guidance, self-efficacy and motivation to work are above 0.7. So, all four variables are reliable, which means that the indicators used for the observed variables for the latent constructs can be said to have been able to explain the constructs or latent variables.

The coefficient of determination $\left(R^{2}\right)$ was used to assess whether certain independent latent variables have a substantive effect or not on the dependent variable. The results of this determination coefficient can be seen in Table 3 below.

Based on the results, the coefficient of determination for work readiness is 0.258 . This means that around $25.8 \%$ of work readiness scores that can be explained by career guidance, self-efficacy and motivation, while the remaining $74.2 \%$ is explained by other variables which are not examined in the model. The coefficient of determination for motivation for work is 0.078 . That is, $7.8 \%$ of motivation to work scores can be explained by career guidance and self-efficacy while the remaining $92.2 \%$ is explained by other variables which are not examined in this model. The coefficient of determination for self-efficacy is 0.160 . This means that $16 \%$ of self-efficacy scores can be explained by career guidance by while the remaining $84 \%$ is explained by other variables which are not examined in this model.

Table 3 Results of coefficient determination

\begin{tabular}{lc}
\hline \multicolumn{1}{c}{ Variable } & Value $\mathrm{R}^{2}$ \\
\hline Work Readiness $(\mathrm{Y})$ & 0.258 \\
Motivation to Work $\left(\mathrm{X}_{3}\right)$ & 0.078 \\
Self-Efficacy $(\mathrm{X} 2)$ & 0.160 \\
\hline Source: Processed primary data, Feb. 2018
\end{tabular}

Furthermore, the predictive relevance value $\left(\mathrm{Q}^{2}\right)$ measures how well the observed values generated by the model and estimation parameters. A model is considered to have relevance predictive value $\left(\mathrm{Q}^{2}\right)$ when $\mathrm{Q}^{2}>0$. The results of $\mathrm{Q}^{2}$ in this study is 0.426 , which show that the predictive model is of great relevance.

\section{Hypotheses testing}

Hypotheses testing aims to provide answers to research problems formulated in this study, namely, the effect of exogenous latent constructs to the endogenous latent constructs. The results of the hypotheses test can be seen in Table 4 . The results show that all $\mathrm{H}_{0}$ are rejected and all alternative hypotheses (Ha) are supported because of $t$-statistic values that are greater than the $t$-table values at significance level (alpha) 0,05.

The results of SEM analysis show that all research hypotheses proposed in this study are supported. First, career guidance has a significant and positive impact on self efficacy. It is marked with t-statistic value of 12,141 which is higher than $t$-table of 1.96 . The coefficient value of 0.401 indicating the magnitude of the effect of career guidance on self-efficacy. According to Rahman (2010), students are able to understand their potential through career guidance by recognizing their interests, talents, attitudes, skills, and aspirations, and aims to increase students' knowledge and self-efficacy. Furthermore, Wright and Meyer (2017) say that career guidance is very important for students' academic success. Based on these findings, career guidance can shape student self-efficacy for the better. In particular, career guidance aims to assist students in achieving their developmental tasks that include personal, social, academic, and career aspects. 
Table 4 Results of hypothesis testing

\begin{tabular}{|c|c|c|c|c|}
\hline Variable & $\begin{array}{l}\text { Original } \\
\text { Sample } \\
(\mathrm{O})\end{array}$ & $\begin{array}{l}\text { Standard } \\
\text { Deviation } \\
(\text { STDEV) }\end{array}$ & $\begin{array}{l}\text { Standard } \\
\text { Error } \\
\text { (St. err) }\end{array}$ & t statistics \\
\hline Career Guidance --> Self-Efficacy & 0.401 & 0.033 & 0.033 & 12.141 \\
\hline $\begin{array}{l}\text { Career Guidance-->Motivation to } \\
\text { Work }\end{array}$ & 0.166 & 0.034 & 0.034 & 4.864 \\
\hline $\begin{array}{l}\text { Self-Efficacy --> Motivation to } \\
\text { Work }\end{array}$ & 0.167 & 0.041 & 0.041 & 4.069 \\
\hline $\begin{array}{l}\text { Career Guidance --> Work } \\
\text { Readiness }\end{array}$ & 0.141 & 0.033 & 0.033 & 4.259 \\
\hline Self-Efficacy --> Work Readiness & 0.389 & 0.042 & 0.042 & 9.088 \\
\hline $\begin{array}{l}\text { Motivation to Work -> Work } \\
\text { Readiness }\end{array}$ & 0.118 & 00039 & 0.039 & 2.999 \\
\hline
\end{tabular}

Source: primary data processing result, Feb. 2018

Career guidance has a significant and positive impact on the motivation to work. It is marked with the $t$-statistic value of 4.864 which is higher than $t$-table of 1.96 . The coefficient value of 0.166 shows the magnitude of influence of career guidance on the motivation to work. This is in line with research conducted by Isnawati (2016), which report that the effective implementation of career counseling services will improve self-understanding and the environment, greater confidence, and increased work motivation. Furthermore, Alfan (2014) show that students will be motivated to enter the workforce with good career guidance. Based on these findings, it can be said that career guidance affects students' motivation to work. It is essential to provide career guidance in schools to create students' independence in choosing a career and to provide expectations to be achieved for future career. It is hoped that schools and teachers can improve their career counseling services through career-based students' activity programs that improve students' motivation to achieve the desired goals.

Self-efficacy has a significant and positive impact on the motivation work. It is characterized by $\mathrm{t}$ statistic value of 4,069 which is higher than t-table of 1.96. Meanwhile, the coefficient value of 0.167 shows the magnitude of the influence of self-efficacy on motivation to work. This is in line with Reddan (2016) that shows that students who have high self-efficacy have a great level of motivation and performance in the workplace. Ormrod (2008) says that self-efficacy is a person's assessment of his own ability to achieve certain behaviors or specific goals. Based on these findings, it can be said that selfefficacy affects students' motivation for work. Self-efficacy affects the internal condition of a person, especially their motivation for work. So that, having a high self efficacy can increase students' confidence to face intense competition in the business and industry.

Career guidance has a significant and positive impact on work readiness. It is marked with the tstatistic value of 11.603 which is higher that $t$-table of 1.96 . The coefficient value of 0.141 indicates the magnitude of the effect given by career guidance on the work readiness. This is in line with Munro's (2005) research which reports that providing maximum career guidance to students will improve students' work readiness by supplying them with knowledge of the diverse jobs available. Further, Mudulia (2017) concludes that career guidance has a significant and positive impact on job readiness. Theresa (2015) reports that career guidance should get special attention because students can find information about work from the career guidance. Based on the findings of several studies, it can be said that career guidance plays a role on students' readiness for work. Career guidance is one service that can help students in career planning and decisions. That is, students need to understand themselves such as their abilities, potentials, talents, interests, personalities, and achievements.

Self-efficacy has a significant and positive effect on work readiness. It is marked with the t-statistic 9.088 which is higher than $\mathrm{t}$-table of 1.96 . The coefficient value of 0.389 shows the magnitude of the effect given by self-efficacy on work readiness. This is in line with Li and Goh (2011) who emphasize 
on the importance of special education and professional vocational rehabilitation with information on the importance of self-efficacy and recommends for interventions aimed at developing student independence to improve their work readiness. Furthermore, Esen (2017) says that self-efficacy relates to students' beliefs about their own ability that ultimately makes students ready to work. Based on the findings, it can be said that self-efficacy is closely related to work readiness. Self-efficacy is a person's judgment of himself about how great his ability in doing a particular task to achieve certain results. Furthermore, self-efficacy is considered reliable in predicting the scope of career choice, work interests, tenacity in difficult areas and personal effectiveness.

Motivation to work has a significant and positive impact on work readiness. It is characterized by the $t$-statistic value of 2.999 which is higher than t-tables value of 1.96 . The coefficient value of 0.118 shows the magnitude of the effect given the construct of career guidance on the readiness of work. This is in line with the research conducted by Kniveton (2004) which reports that the most dominant factor affecting students' work readiness is the motivation derived from their external environment, such as parents (family), teachers (another school environment), gender, and so on. Fajriah (2017) shows that motivation to work is the key and the beginning formation of students' work readiness. Furthermore, Pujianto (2016) reports that students who have high motivation to work are usually more ready and eager to work later. Based on the findings, it can be concluded that motivation to work is an important factor in shaping student' work readiness. Students who have the motivation to work will make every effort to be accepted into work filed such as providing themselves with various skills and attitudes needed in the work field.

\section{Conclusions}

Students' work readiness is one of important aspects to be prepared before they join the workforce. Students who is physical, mentally, and able to work well will be more successful in their work than the unprepared students. The intense competition of finding jobs today requires students to embrace competition in order to compete with other job seekers.

The results of this study show the indirect and direct influence on students' work readiness. First, career guidance and self-efficacy have indirect effects on students' readiness through motivation to enter the workforce. This shows that career guidance and self-efficacy play a role in motivating students to be ready for work. This process was created by providing information from counseling teachers, sharing experiences and stories with friends, and other matters related to students' readiness. Second, career guidance, self-efficacy, and motivation to enter the work world have direct effects on students' work readiness.

\section{Acknowledgments}

The authors would like to express their sincere gratitude to vocational high schools (SMK Negeri) of Business and Management in city of Pariaman and Padang Pariaman regency that have participated in this research.

\section{References}

Brady, R. P. (2010). Work Readiness Inventory - Administrator' S Guide. JIST Works, 1-16.

Cabellero, C., Walker, A., and Tyszkiewicz, M. F. (2011). The work readiness scale (WRS): Developing a measure to assess work readiness in college graduates. Journal of Teaching and Learning for Graduate Employability, 2(2), 41-54. https://doi.org/10.1111/1744-1609.12044.

Fajriah, U. N., and Sudarma, K. (2017). Pengaruh praktik kerja industri, motivasi memasuki dunia kerja, dan bimbingan karir pada kesiapan kerja siswa. Economic Education Analysis Journal, 6(2), 421-32.

Jenkins, L. N., and Demaray, M. K. (2011). Relations among academic enablers and academic achievement in children with and without high levels of parent-rated symptoms of inattention, impulsivity, and hyper activity. Psychology in the Schools, 48(6), 573-86. https://doi.org/10.1002/pits.20578. 
Mu'ayati, R. and Margunani. (2014). Pengaruh praktik kerja industri (prakerin), penguasaan mata diklat produktif akuntansi dan minat kerja siswa terhadap kesiapan menghadapi dunia kerja siswa SMK program keahlian akuntansi di SMK N 1 Salatiga tahun ajaran 2013/2014. Economic Education Analysis Journal, 3(2), 327-35.

Muktiani, E. E. (2014). Pengaruh praktik kerja industri dan prestasi akademik mata diklat produktif akuntasi terhadap kesiapan kerja siswa kelas XI program keahlian akuntansi SMK Nasional Pati tahun pelajaran 2012/2013. Economic Education Analysis Journal, 4(1), 166-72.

Noviana. (2014). Pengaruh hasil belajar mata pelajaran produktif akuntansi, program praktik kerja industri, dan self efficacy terhadap kesiapan kerja siswa kelas XII program keahlian akuntansi di SMK Negeri 1 Kendal tahun ajaran 2013/2014. Economic Education Analysis Journal, 3(1), 18290.

Pujianto, S. A. (2017). Pengaruh pengalaman on the job training dan motivasi memasuki dunia kerja terhadap kesiapan kerja siswa. Economic Education Analysis Journal, 6(1), 173-87. https://doi.org/ISSN 2252-6544.

Smith, C. (2016). Designing work-integrated learning placements that improve student employability: Six facets of the curriculum that matter. Asia-Pacific Journal of Cooperative Education, 17(2), 197211.

Theresa, L. D. (2015). Factors that inform students' choice of study and career. Journal of Education and Practice, 6(27), 43-50.

Ward, V. G., and Riddle, D. I. (2002). Ensuring effective employment services. NATCON Papers 2002 Les Actes Du CONAT, 1(1), 1-9.

Wasylkiw, L. (2016). Students' perspectives on pathways to university readiness and adjustment. Journal of Education and Training Studies, 4(3), 28-39. https://doi.org/10.11114/jets.v4i3.1197.

Willison, J. B. and Suniti. (2015). Building capacity for work-readiness: bridging the cognitive and affective domains. Asia-Pacific Journal of Cooperative Education, 16(3), 223-33. https://doi.org/10.5204/intifyhe.v4i1.156.

Wright, A. M., and Meyer, K. R. (2017). Exploring the relationship between students needing accommodations and instructor self-efficacy in complying with accommodations. Higher Learning Research Communications, 7(1), 65-83. https://doi.org/10.18870/hlrc.v7i1.367.

Zachim, A. M. (2014). Pengaruh bimbingan karir dan lingkungan sekolah melalui motivasi kerja terhadap kesiapan kerja siswa kelas XII kompetensi keahlian akuntansi SMK NEGERI 2 Magelang. Economic Education Analysis Journal, 3(1), 114-23. 